\title{
Diversity of Shrub Plants in Kapas Biru Waterfall Lumajang District of East Java
}

\author{
Barid Firdausy $^{1}$, Pujiastuti ${ }^{2}$, Siti Murdiyah ${ }^{3}$ \\ ${ }^{1}$ Faculty of Teacher Training and Education, University of Jember \\ email: pujiastuti.fkip@unej.ac.id \\ ${ }^{2}$ Faculty of Teacher Training and Education, University of Jember
}

\begin{abstract}
The high diversity of plant species makes the Kapas Biru Waterfall a suitable area of tourism, research and other related activities. The plant species in this area are mostly seed plants and shrub. The shrub is a tree-like plant but with shorter and smaller main stem. The woody stems alsobranching near the surface of the soil. The aim of this research was to find out the species of shrub plants in the area of Kapas Biru Waterfall. This descriptive explorative research was conducted to systematically, factually and accurately describe and interpret the data of shrub seed plants in the area of Kapas Biru Waterfall. The study was conducted from April to May 2017. The research design included the selection of research sites, sampling and drawing, and plant identification stages.Samples were collected using total explore sampling method. Research result showed that there are 562 shrub plants in Kapas Biru Waterfall. They consist of 19 species incorporated in 11 families. Those family are Asparagaceae, Rutaceae, Asteraceae, Euphorbiaceae, Oleaceae, Arecaceae, Verbenaceae, Rubiaceae, Melastomataceae, Solanaceae, and Araliaceae.
\end{abstract}

Keywords: Identifying, Kapas Biru, Shrub plants

\section{INTRODUCTION}

Indonesia is located in an equatorial region that has a unique type of tropical rainforest, and is one of the world's richest diverse plant species. About 40,000 species of flora are grown in the world, 30 thousand of which are grown in Indonesia, and 10\% of the world's flowering plant species are grown in Indonesia [9] [23]. About 26\% from that amount is cultivated plant species and the remaining $74 \%$ are wild vegetation in the forest [11]. The rich diverse plants happens because the natural conditions of Indonesia are different from one island to another island, even from one place to another place in the same island. A blend of unique biological resources and living spaces will cultivate a variety of ecosystems, presenting the specificity in the life of the species they contain. [8]

Indonesia is also a country with high levels of biodiversity vulnerability. LIPI's Deputy of Life Sciences (IPH), describes 393 species of endangered Indonesian plants based on data disclosed by the International Union for Conservation of Nature (IUCN). In addition to agriculture and urbanization, threats also come from logging and crop cutting and invasive plant invasion. [13] There is a serious effort in maintaining and preserving the diversity available so as not to become extinct. [16] One effort to preserve the diversity of plants is through inventory and identification.

The konowledge of diversity is one of the basic conservation efforts, so if diversity is maintained today and in the future, and the sustainability of diversity functions is maintained. Based on IUCN data, the amount of plant diversity is constantly changing from year to year, from one place to another, and tends to decline. Based on these facts it is very important to know the biodiversity. One of the areas in Indonesia that has an ecosystem with a high diversity of plants, namely in the area of Kapas Biru waterfall. Blue cotton waterfall is located in District Pronojiwo Lumajang East Java Province. The area of the Blue Cotton waterfall lies in the position of $7^{\circ}$ 52 's to $8^{\circ} 23^{\prime}$ ' South Latitude and $112^{\circ} 50$ 's to $113^{\circ} 22^{\prime}$ East Longitude. Boundary of Kapas Biru waterfall area, north of Mount Semeru, east of Candipuro District, south of Tempursari District and west of Malang Regency. kapas Biru Waterfall area is 35 $\mathrm{km}$ from downtown Lumajang and $50 \mathrm{~km}$ from Malang city [4]. The height of the 
waterfall area, which is 521 meters above sea level. This area also has a fairly high rainfall, which has an average number of dry months 3 months in 1 year, so the area is classified into wet climates [17]. Environmental factors and adequate climate make this area into one of the green areas in Lumajang Regency. Blue cotton waterfall area is one of the new tourist attraction in the district Pronojiwo. Tourism area which has an area of about 38 ha, was opened in July 2015, until in september 2016. Kapas Biru waterfall area established and managed by the government with the cooperation of Forest Proponition Unit (KPH) Probolinggo area, as a tourist area and conservation areas [5].

The high diversity of plant species makes the Kapas Biru Waterfall Area as a suitable area in supporting tourism, research and other related activities. The results of initial observations found a variety of plant species in this area. In the observed plant type area include several plants with tree habitat, habitable groves covering the species of asoka, jasmine, beluntas and several species of moss and fern plants. In the area of the path, the vegetation includes a tree-like plant, a vegetation that includes terna plants and shrubs, and fern and moss plants that attach greatly to the walls of walkways and cliffs. The shruby habitus plant observed in this area is one of the most prominent plant species and puring plant in this area.

Plants in the area around the waterfall observed by researchers are fern and moss plants are quite a lot on the rocks and cliffs around the waterfall, some plants with tree habitus, and plants that cover the plants and shrubs terna. Plants with shrub habitus observed in this area are amethyst species and 3 other unidentified plant species. The head of the Forest Pruning Resort (KRPH) Pronojiwo once conducted a data collection of plants in the waterfall area, but only on the tree vegetation, ie there are 12 species of trees present in this waterfall area, while for vegetation plants with shrub habitus has not been done data collection of diversity.
Given the supportive natural conditions, the high diversity of plant species and their preserved authenticity has the potential to be utilized as a source of learning while maintaining its sustainability [4].

Environmental conditions created are supported by the many species of plants. One component in the vegetation community is the lower plants. The lower plants consist of all types of basic vegetation found under forest stands except for young trees. Most of these plant groups are seed plants with shrubs habitus. The shrubby plant is a tree-like plant but with a short, smaller stem, woody stem, and branching near the ground [2] [24]. Integrated efforts to manage and conserve shrubs are still not visible. Based on preliminary observations, with large quantities and high biodiversity, the biodiversity potential for shruby habitation seed plants is not widely known because of the lack of research and inventory of flora, so that the ecological and economic value of vegetation has not been well identified [29] .

In the process of data collection of plant diversity is needed an identification process, one of them with the use of scientific name. Identification activity is the determination of plant identity, that is determining the correct plant name and its proper place in the classification system. The identification activity aims to find common ground, since the scientific name, is the name of the international standard [7]. Plants to be identified are likely to be unknown to the world of science, so the new name determination, or the level of its taxon, must follow the rules contained in the KITT (International Code of Plant Nation). Recognized plants can be identified through plant experts, specimens, herbaria, flora books, or key determinations [10].

\section{RESEARCH METHOD}

\section{Types of research}

This research includes descriptive explorative research. This descriptive 
method describes the condition of the object of study in accordance with the circumstances found or observed in the field. The result is a detailed description of the object under study and described systematically, factually and accurately. While the explorative method is a direct research into the field to dig the data without testing the concept on the reality under study.

\section{Place and time of research}

Identification of hollow shrub seed plants was conducted in April 2017 to May 2017. The location of the research was conducted in the area of Kapas Biru Waterfall of Pronojiwo Sub-district, Lumajang Regency, East Java Province. Sampling is done on 3 locations in the area of the parking lot, the path to the waterfall, the area under the waterfall. If the samples are found to have difficulties or can not be identified, the sample will be sent LIPI UPT Balai Konservasi Botanical Garden Purwodadi Botanical Garden.

\section{Tools and Materials Research}

The tools used in this study include: hygrometer (temperature and humidity), soil tester (soil $\mathrm{pH} \&$ soil moisture), altimeter application, stationery, camera, plastic, cetok, scissors, plant nameplate, ruler and GPS, literature: Plant Taxonomy (Spermatophyta): Gembong
Tjitrosoepomo, 2007; An Introduction to Taxonomy of Angiosperms: Priti Shukla, 1997; Native Tree, Shrub, and Herbaceous Plant Identification: Ronald L Alves, 2014 and Flora for Schools in Indonesia: C.G.G.J. van Steenis, 2013. Materials used in this study include: species of shrubbed habitation seed plants.

\section{Sampling Method}

The sampling method consists of sampling and drawing. Sample retrieval method is using roaming method which is done by walking down the research location or exploring per research area

\section{RESULT AND DISCUSSION}

The study was conducted in the area of Blue Cotton Waterfall from April to May 2017 obtained by 19 samples of plants. Table 2 Data of shrub plants of Kapas Biru Waterfall Area. Identification of 19 samples was conducted on observation day.

There are 10 unidentified samples, then sent to UPT Cibodas Botanical Gardens Conservation Center LIPI, in July 2017. The following is the data of environmental factors and dabit of habitable habitat found in Kapas Biru Waterfall Area.

Table 1 Average data of environmental factor measurement of Kapas Biru Waterfall Area.

\begin{tabular}{|c|c|c|c|c|}
\hline Species Name & $\begin{array}{l}\text { Common } \\
\text { Name }\end{array}$ & Number & Location & GPS coordinate \\
\hline $\begin{array}{l}\text { Lasianthus } \quad c f \\
\text { purpureus }\end{array}$ & Lasiantus & 24 & Roads trails & $\mathrm{S} 08^{0} 13.552 \mathrm{E} 112^{0} 56.261$ \\
\hline $\begin{array}{l}\text { Lantana } \\
\text { camara } \mathrm{L}\end{array}$ & Tembelekan & 44 & Roads trails & $\begin{array}{l}\text { S } 08^{0} 13.551 \mathrm{E} 112^{0} 56.275 \\
\text { S } 08^{0} 13.322 \text { E } 112^{0} 56.470\end{array}$ \\
\hline $\begin{array}{l}\text { Coffea } \\
\text { canephora }\end{array}$ & Kopi & 90 & $\begin{array}{l}\text { Roads trails } \\
\text { and area } \\
\text { around } \\
\text { waterfall }\end{array}$ & $\begin{array}{l}\text { S } 08^{0} 13.556 \text { E } 112^{0} 56.317 \\
\text { S } 08^{0} 13.456 \text { E } 112^{0} 56.272 \\
\text { S } 08^{0} 13.450 \text { E } 112^{0} 56.271 \\
\text { S } 08^{0} 13.322 \text { E } 112^{0} 56.470 \\
\text { S } 08^{0} 13.311 \text { E } 112^{0} 56.390\end{array}$ \\
\hline $\begin{array}{l}\text { Clidemia } \\
\text { hirta }(\text { L.) }\end{array}$ & $\begin{array}{l}\text { Harendong } \\
\text { bulu }\end{array}$ & 55 & $\begin{array}{l}\text { Roads trails } \\
\text { and area }\end{array}$ & $\begin{array}{l}\text { S } 08^{0} 13.456 \text { E } 112^{0} 56.272 \\
\text { S } 08^{0} 13.556 \text { E } 112^{0} 56.317 \\
\end{array}$ \\
\hline
\end{tabular}




\begin{tabular}{|c|c|c|c|c|}
\hline & & & $\begin{array}{l}\text { around } \\
\text { waterfall }\end{array}$ & $\begin{array}{l}\text { S } 08^{0} 13.331 \text { E112 } 12^{0} 56.456 \\
\text { S } 08^{0} 13.322 \text { E112 }\end{array}$ \\
\hline $\begin{array}{l}\text { Mussaenda } \\
\text { frondosa }\end{array}$ & Kingkilaban & 40 & $\begin{array}{l}\text { Roads trails } \\
\text { and area } \\
\text { around } \\
\text { waterfall }\end{array}$ & $\begin{array}{l}\text { S } 08^{0} 13.322 \text { E } 112^{0} 56.470 \\
\text { S } 08^{0} 13.331 \text { E } 112^{0} 56.456 \\
\text { S } 08^{0} 13.551 \text { E } 112^{0} 56.253\end{array}$ \\
\hline $\begin{array}{l}\text { Solanum } \\
\text { torvum } \mathrm{Sw}\end{array}$ & Takokak & 12 & $\begin{array}{l}\text { Roads trails } \\
\text { and area } \\
\text { around } \\
\text { waterfall }\end{array}$ & $\begin{array}{l}\text { S } 08^{0} 13.331 \text { E } 112^{0} 56.456 \\
\text { S } 08^{0} 13.325 \text { E } 112^{0} 56.436\end{array}$ \\
\hline $\begin{array}{l}\text { Datura } \\
\text { metel L }\end{array}$ & $\begin{array}{l}\text { Kecubung } \\
\text { putih }\end{array}$ & 5 & $\begin{array}{l}\text { Area } \\
\text { around } \\
\text { waterfall }\end{array}$ & S $08^{0} 13.278 \mathrm{E} 112^{0} 56.440$ \\
\hline $\begin{array}{l}\text { Polyscias } \\
\text { scutellaria }\end{array}$ & MangKokan & 1 & $\begin{array}{l}\text { Area } \\
\text { around } \\
\text { waterfall }\end{array}$ & S $08^{0} 13.296 \mathrm{E} 112^{0} 56.456$ \\
\hline
\end{tabular}

Table 2 Data of shrub plants in the Kapas Biru Waterfall Area.

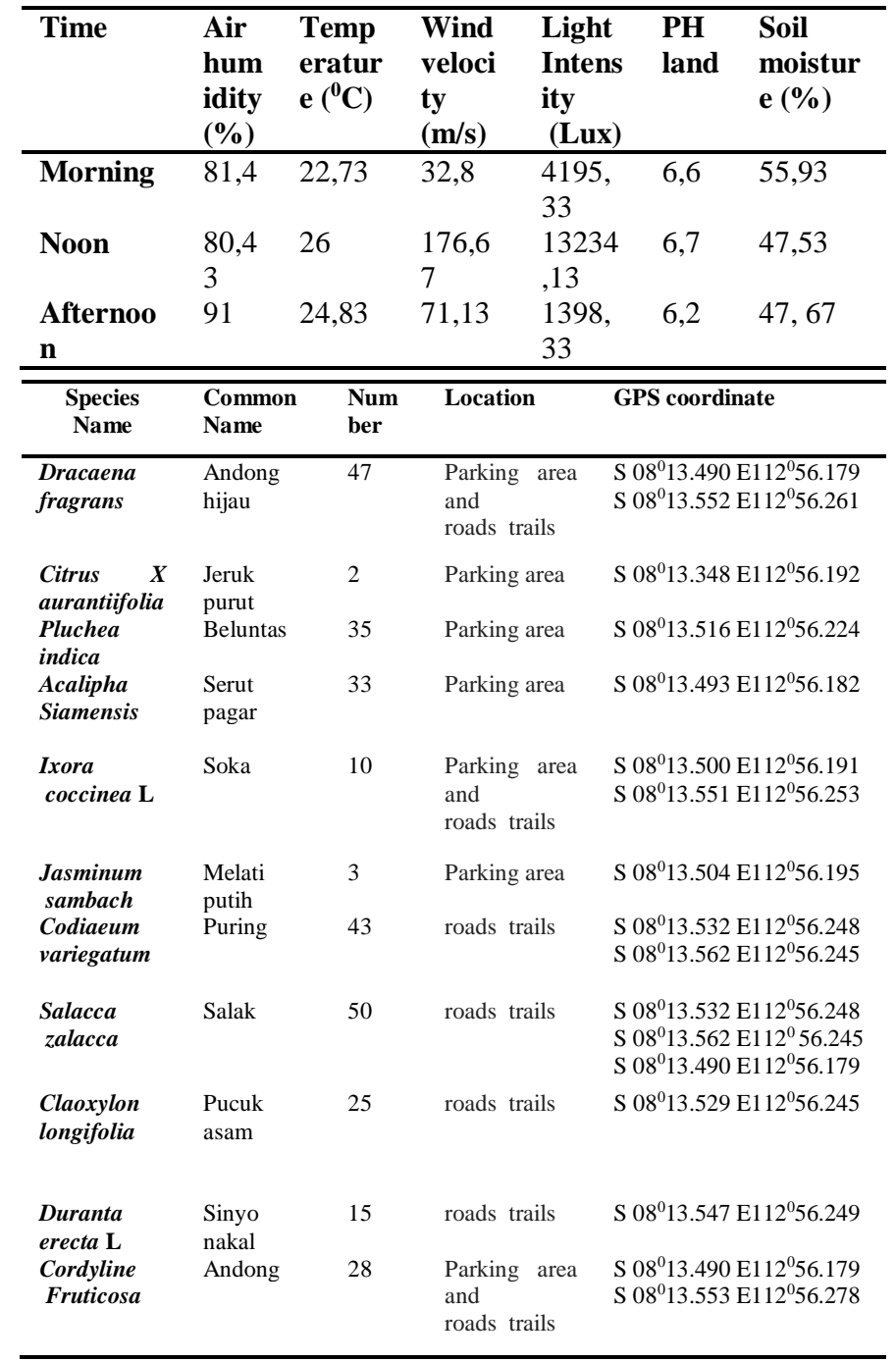

\section{Bioedukasi Vol. XVI. No.1 April 2018}




\section{Identification of the shrubby Plants in the Blue Cotton Falls Area}

Research on the diversity of shruby plants with shrubs in the area of blue cotton waterfall has been done. The identification was done on samples of hollow shrunken shrub plants found and do herbarium making. The number of species found throughout the research area is 19 species. There are nine species of shrunken shrub plant species identified in the Steenis Flora Book for Schools, Drug Efficacious Atlas of the Medicines and ITIS, so 10 of the 19 species are sent to the Plant Conservation Center of Cibodas Bogor Botanical Garden - LIPI

The results showed that there were 19 species of shrunken shrub plants in Table 2, namely, sample 1 , with the general name green andong, and the Dracaena fragrans type name, sample 2, with the common name of Kaffir, and the type name Citrus X aurantiifolia, sample 3, with the common name Beluntas, and the name of the type Pluchea indica, sample 4, under the general name Teh Tehan, and the name Acalipha siamensis Oliv.ex Gage, sample 5, with the common name Soka, and the Ixora coccinea L, sample 6, with the common name Melati putih, and the Jasminum sambach type name, sample 7 , under the common name Puring, and the type name of Codiaeum variegatum, sample 8 , with the common name Salak, and the Salacca zalacca species name, sample 9, Common shoots of acid, and the name of Claoxylon longifolia (Blume) Endl.ex Hassk, sample 10 , with the common name of Sinyo naughty, and the name of Duranta erecta $\mathrm{L}$ type, sample 11, under the general name Andong, and the name Cordyline Fruticosa LA Cheval, 1 12, with the common name Lasiantus, and the name of the type Lasianthus cf purpureus Blume, sample 13, under the general name of Recess, and the Lantana camara L type, sample 14, with the common name Coffee, and the name of the type Coffea canephora, sample 15, general Harendong fur, and the type name Clidemia hirta (L.) D. Don, sample 16, with the common name Kingkilaban, and the type name Mussaenda frondosa, sample 17, with the common name Takokak, and the name of Solanum torvum Sw type, sample 18, with common name Amethyst white, and name of type Datura metel L, sample 19, with common name Mangkokan, and name of type Polyscias scutellaria

The samples obtained at 3 sampling sites are generally distributed around the parking area, the edge of the path, and partly close to the water source, around the waterfall object. The shrubs are widespread throughout the area, whose specific location is determined through a GPS application. In addition, samples of shrub plants found in these different areas are influenced by supporting environmental factors. Environmental factors include temperature, humidity, soil moisture, soil $\mathrm{pH}$, wind speed, and light intensity.

\section{Linkage of shrubby plants with abiotic factors}

The shrubs found in the Blue Cotton waterfall area are 19 species. Shrubs are found in addition to wild plants also contain shrubs in the form of ornamental plants and plantation crops. The average daily temperature in the area of Blue Cotton Waterfall is the morning of $22,730 \mathrm{C}$, at day $260 \mathrm{C}$, and afternoon $24,830 \mathrm{C}$. The average temperature is suitable and ideal for shrubs to grow, in which shrubs are able to grow at a temperature range of 15-400C [22]. Shrubs that are able to grow well at the average temperature is monitored coffee and jasmine. Coffee and jasmine plants grow well and are able to bloom at daytime temperatures of 28-360 $\mathrm{C}$ and at night temperatures yairu 23-300C. Temperature is very influential in the growth and development of plants, because the temperature plays a major role in the rate of metabolism, photosynthesis, respiration, and transpiration of plants. Temperatures that are too high can damage the enzymes so that the rate of plant metabolism also will not run properly. Temperatures that are too low can also cause the enzyme to be 
inactive, so the metabolic rate stops [6]. The abundance of certain plant species is also influenced by other environmental factors such as light intensity, wind speed, soil moisture, air humidity, and soil $\mathrm{pH}$. Abiotic factors that affect the large temperature range that forms a microclimate around the location, thus affecting the least amount of vegetation in the location.

The average air humidity in Table 1 is the location of the study area ie morning $81.4 \%$, afternoon $80.43 \%$, and afternoon $91 \%$. In the average data of air humidity in the afternoon there is anomalous data, where data is far adrift with data of average air humidity in the morning and afternoon. This could happen because of several factors, the first time of data retrieval. Abiotic data collection in the morning, conducted at 9 to $10 \mathrm{am}$, where the sun is also a bit hot and moisture content in the air is also a little, thus affecting the data of air humidity. The second factor is the direction of the sun. The data collection area is located between hills and valleys, when morning and afternoon, the data collection area, in the direction of the sun, so that the lighting is relatively higher. While in the afternoon, the data collection area in opposite direction with the arrival of sunlight and obstructed by the hill, so the lighting is also relatively low. High lighting causes evaporation, and decreases air humidity, thus affecting air moisture data. Relative humidity $(\mathrm{RH})$ required for shrub plants ranges from $30-80 \%$. Thus, this plant is able to grow in dry areas or even relatively wet. Humidity functions for plants, among others, to avoid too high evaporation that can cause dehydration. So the location of Blue Cotton Waterfall is a compatible location for the shruby vegetation plant [20].

In addition to the air humidity that affects the shrub plants there is also the intensity of light that can affect the metabolism of plants, especially in the process of photosynthesis. Without sunlight, the process of growing and developing shrub plants will be hampered.
Each Shrub plant needs light with varying intensity. Based on Table 1, the observed average light intensity range is morning 4195,33 lux, afternoon 13234,13 lux, and 1398.33 lux. The intensity of this light in the shrubs is very influential on the structure of morphology to physiological, for example, in plant salak and plant puring. Salak plants are very susceptible to direct sun exposure, this plant requires a light intensity of 30 to 70 percent sun, because it is necessary for shade plants [18]. If the intensity of light received by excessive salak plants, it will result in high evaporation, so the flowers will quickly dry up before pollination and fruit formation will be hampered [26].

In contrast to the puring plant, in its natural habitat, puring plants grow in the open with full sun, does not require shade. Some types of bright leafy puring, will be more visible sharp / clear leaf color when exposed to sunlight. The sample of the puring plant found has a height not too high, and is under the auspices of another higher plant, so the color of the leaves is not brilliant, the dominant color that appears only green with a little yellow spots, the leaves are smaller and narrower but the leaves will be more thick. The number of abundance of plant samples found, that the number of puring plants is also less than the salak plants. From the statement that the intensity of light affects the growth of shrub plants [22].

Shrubs are also affected by wind speed. Based on Table 1 the average wind speed range is $32.8 \mathrm{~m} / \mathrm{s}$, afternoon 176,67 $\mathrm{m} / \mathrm{s}$, and afternoon $71,13 \mathrm{~m} \mathrm{/} \mathrm{s}$. Wind velocity affects the reproduction process of shrub plants, namely the process of pollination and seed dispersal process. The shrubs that are in the process of pollination are aided by the wind, characterized by small flowers, large numbers of flowers and light, and do not produce nectar or odor [11]. Shrubs plants that spread seeds with wind aids generally have characteristics of small seed size, lightweight and have additional adaptation tools in the form of 
wings. The growth of seeds that fall on the ground is also supported by soil conditions one of soil moisture and soil $\mathrm{pH}$. The average yield of the soil $\mathrm{pH}$ range in Table 1 sampling area was morning 6.6, noon 6.7, and 6.2. While the average yield of soil moisture range that is morning $55,93 \%$, afternoon $47,53 \%$, and afternoon $47,67 \%$.

$\mathrm{Ph}$ land is one of the environmental factors measured at the sampling site. Ph land affects the absorption of soil elements by plants. Shrubs can generally grow well in the range of 5.5 to 6.8 . At $\mathrm{pH}>7.0$ some shrubs often show symptoms of chlorosis, ie dwarf plants and yellowing leaves due to iron nutrient deficiency (Fe). At $\mathrm{pH}<5.5$ shrub plants will also grow dwarf due to lack of $\mathrm{Ca}, \mathrm{Mg}$ and $\mathrm{P}$ or $\mathrm{Al}$ and $\mathrm{Mn}$ toxicity, other than that too low soil or acidic soil, potentially damaging the young roots of plants [25].

\section{Linkage of Shrubs with Biotic Factors}

The growth of shrubs is not only influenced by abiotic factors, but also influenced by biotic factors. Biotic factors are factors influenced by living things such as plants, animals, or humans. The Blue Cotton Falls area has many tall trees with wide canopy to form a canopy structure that houses the plants below it. Some types of trees that exist in the area of blue cotton waterfall is bendo wood, banyan tree, wood flower, sengon albasia, bamboo, cloves, durian, petai, kelengkeng, waru gunung, mahoni. The presence of shade trees causes a decrease in the intensity of light received by shrub plants that generally have lower altitudes and are located below the forest floor. Each shrub plant needs light with varying intensity, especially in the process of photosynthesis [27]. Shrubs, such as salak, are particularly vulnerable to direct sun exposure due to excessive light intensity, which will result in high evaporation, so the flowers will quickly dry out before pollination occurs [18]. But there are also shrub plants that can grow in the open with full sun, and do not require shade one of which is a puring plant [22]. If the intensity of light received perdu plants is not appropriate, it will greatly affect the metabolism and productivity of plants, especially in the morphological structure to physiological activities.

The second biotic factor that influences the shrub plants in the Blue Cotton waterfall area is human. The samples of shrub plants found in the majority, the morphological part is less complete, either lack of flower or fruit organ. This can happen because apart from the physiological factors of plants, it could also result from pruning by humans. Sampling is done in the parking lot, along the path, to the area, around the waterfall. The third area is an area that is often passed by humans, because it is the main access road to the waterfall. Provision of sampling is 1.5 meters to the right and left on the path area, so the distance between the path and sampling is not too far away. When the plants reach a certain size, too dense and obstruct the path, the officers from the Hall Perhutani will cut the plant, to clean the area, so accidentally cut some parts of the plant.

The third biotic factor that influences on growth and spread of shrub plants in blue cotton waterfall is animal. The area of Kapas Biru waterfall is a conservation area, so all forms of hunting are prohibited in this area. Some species of mammals, or birds are still found in this area. When the research process of some animals that had been observed were long-tailed monkeys, Javan langurs, fruit bats, some bird species, and some species of insects. These animals generally like to eat fruit, so that these animals in shrubs have a role as pollinating agent and seed dispersal, so it will increase the chance of seed to grow and develop well into new shrubs.

\section{The Uniqueness of the Founded Group of Shrubs}

Group of Shrub plants have their own uniqueness and character. The nature and character of each plant are not the same, one with the other. These traits and 
characteristics show the characteristics and identity of each plant. Distinctive characteristics and differences of plant identity are considered as species diversity. Identification in the study was conducted by observing the characteristics of morphological features that appear in plants. Characteristics of morphological features used in the process of identification of plant diversity include morphology of stems, leaves, flowers, and fruit, and other characteristics that are seen.

The results of the identification of the diversity of shruby habitation plants were 562 shrubs in the blue cotton waterfall area. The diversity of shrunken habitation seed plants can be seen from the total number of species found, ie 19 species belonging to 11 families. The families are Asparagaceae, Rutaceae, Asteraceae, Euphorbiaceae, Oleaceae, Arecaceae, Verbenaceae, Rubiaceae, Melastomataceae, Solanaceae, and Araliaceae

Family Asparagaceae consists of 2 species of Dracaena fragrans and Cordyline Fruticosa L. A. Cheval. Family Rutaceae consists of 1 species of Citrus X aurantiifolia. Family Asteraceae consists of 1 species of Pluchea indica. Family Euphorbiaceae consists of 3 species namely Acalipha siamensis Oliv.ex Gage, Codiaeum variegatum, and Claoxylon longifolia (Blume) Endl.ex Hassk. Family Rubiaceae consists of 4 species of Ixora coccinea L, Lasianthus of purpureus Blume, Coffea canephora, and Mussaenda frondosa. Family Oleaceae consists of 1 species of Jasminum sambach. Family Arecaceae consists of 1 species of Salacca zalacca. Family Verbenaceae consists of 2 species, Duranta erecta L, and Lantana camara L. Family Melastomataceae consists of 1 species, Clidemia hirta (L.) D. Don. Family Solanaceae consists of 2 species of Solanum torvum Sw, and Datura metel L. Family Araliaceae consists of 1 species namely Polyscias scutellaria (Burm. F.) Fosberg.

The largest number of shrub species is from Family Rubiaceae consisting of 4 species, followed by Family Euphorbiaceae consisting of 3 species. Based on the number of plants, the dominant plants in the area of blue water cascade respectively the Coffea canephora as many as 90 plants, Clidemia hirta (L.) D. Don as many as 55 plants, Salacca zalacca 50 plants, Dracaena fragrans as many as 47 plants, Lantana camara L as much 44 plants. While species of shrubs are the least amount of Polyscias scutellaria as much as 1 plant, Citrus $X$ aurantiifolia as much as 2 plants, Jasminum sambach as many as 3 plants and Datura metel $L$ as many as 5 plants.

Family rubiaceae are the most numerous species among others. The plant samples found in this study consisted of 4 species, Ixora coccinea L, Lasianthus cf purpureus Blume, Coffea canephora, and Mussaenda frondosa. The plant crop of the Rubiaceae family is easily recognizable, that is, through its simple, simple-shaped leaves, the flowered leaves of radial symmetry and into one (simpetally) tubular (tubular), and inferior ovary [3].

The next group of plants that has the second most common spseies is Family Euphorbiaceae. The plant samples found in this study consisted of 3 species, Acalipha siamensis Oliv.ex Gage, Codiaeum variegatum, and Claoxylon longifolia (Blume) Endl.ex Hassk. This plant group has a special character, if the plant part is injured will remove the white sap. Another special feature is the alternate leaf seating type, a simple leaf shape, but when the leaf is compound, the leaf shape is palmate. Stipula modified into hair, thorn, gland or absent in succulent species. Radial symmetry and singular flowers. The genus in Family Euphorbiaceae has pseudanthium (false flowers) and has a special form called cyathium. The fruit is generally a type of fruit scizocarp [1].

Based on the amount, Coffea canephora, with the common name of coffee plants, has the largest number of species in the area of blue cotton waterfall with the number of 90 species. This plant is 
mostly found in the area of the path to the area under the waterfall, which is divided into 5 point coordinates on $\mathrm{Gps}$, the first point is on the coordinates $\mathrm{S} 08^{0} 13.556$ E112 $2^{0} 56.317$, the second point is on the coordinates S $08^{0} 13.456$ E1 $12^{0} 56.272$, the third point is on coordinates $\mathrm{S} 08^{0} 13.450$ $\mathrm{E} 112^{0} 56.271$, the fourth point is at the coordinates S $08^{0} 13.322 \mathrm{E} 112^{0} 56.470$, and the fifth point is at the coordinates $\mathrm{S}$ $08^{0} 13.311 \mathrm{E} 112^{0} 56.390$. The existence of coffee plants in the area of blue cotton waterfalls, namely as plantation crops, where planting of this plant is intentional and regulated by perhutani as a commodity livelihood community around the waterfall. Coffee plants are very easy to recognize in nature, ie from relatively short stems, with oval leaves, the crown of flowers are white and smell nice and we bear fruit, generally fruit clustered. Coffee-shaped fruit rounded, green coffee, and will turn yellow to red, as it gets older [21].

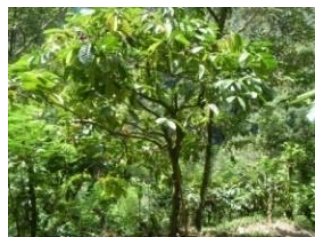

\section{Figure 1. Coffee Plant (Personal} Document)

The second largest number of shrub species is Clidemia hirta (L.) D. Don with the common name of the fur harp. This plant has a number of plants as many as 55 species. Distribution of this species is found in the area of the path to the surrounding area below the waterfall and is divided into 4 point coordinates on $\mathrm{Gps}$, the first point is at the coordinates $\mathrm{S} \quad 08^{0} 13.456$ E112 $2^{0} 56.272$, the second point is at coordinates $\mathrm{S} 08^{0} 13.556 \mathrm{E} 112^{0} 56.317$, the third point is on the coordinates $\mathrm{S}$ $08^{0} 13.331 \mathrm{E} 112^{0} 56.456$, and the fourth point is at the coordinates $\mathrm{S} 08^{0} 13.322$ $\mathrm{E} 112^{0} 56.470$. The plumage of feathers is recognizable in nature, through, a feather that almost covers all parts of the plant, relatively short stems, with oval leaves and reddish-green, purple and white crowns. The fruit type is the buni fruit, characterized by oval and purple features [21]. Species Clidemia hirta (L.) D. Don, is an invasive plant, where this plant will grow and spread out from its natural habitat. The growth of this species, causing a disruption of the growth of other species around it, because these speeches produce allelopathic compounds in the form of phenolic derivatives [12]. So the spreading of this plant area of Blue Cotton waterfall, wide enough.

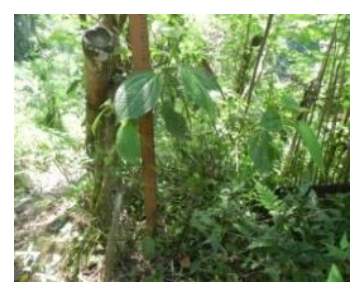

Figure 2. Harendong Feather Plants (Personal Document)

The third largest number of shrubs is Salacca zalacca with the common name of bark, has a total of 50 species. The distribution of this species is found in the parking area and the path area, at 3 point coordinates on Gps, the first point is at the coordinates $\mathrm{S} 08^{0} 13.490 \mathrm{E} 112^{0} 56.179$, the second point is at the coordinates $\mathrm{S}$ $08^{0} 13.532 \mathrm{E} 112^{0} 56.248$ and the third point is at the coordinates $\mathrm{S} 08^{0} 13.562 \mathrm{E} 112^{0} 56$. 245. Character of bark plants, can grow well in wet climates with a $\mathrm{pH}$ of about 6.5 , in the form of sand or clay that is rich in organic matter, can store water and not stagnant, because its root system is shallow [18]. Optimal temperature $20-30^{\circ} \mathrm{C}$, if less than $20^{\circ} \mathrm{C}$ inflorescence will be slow, if too high will cause the fruit and seed to rot. Salak grows well from the lowlands to a height of about 700 meters above sea level and can bear fruit throughout the year [19]. Abiotic factors that are suitable for the growth of salak plants, so salak is found in many areas of Blue Cotton waterfalls. 


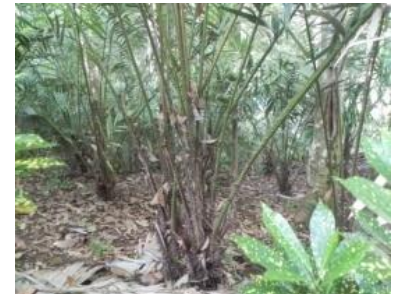

Figure 3. Salak Plant (Personal Document)

The highest number of shrubs is Dracaena fragrans, as many as 47 species. The distribution of this species is found in the parking area and the path area, at 2 point coordinates on Gps, the first point is at the coordinates S $08^{0} 13.490 \mathrm{E} 112^{0} 56.179$ and the second point is at the coordinates $\mathrm{S}$ $08^{0} 13.552$ E112 ${ }^{0} 56.261$ Dracaena fragrans is often known by the common name green andong. Green andong plant has a unique character that is, has a stem structure yamg tum-buh upright, roundshaped, and there are rings-shaped streaks, the former leaves that fall on the surface of the stem. Leaf type, single leaf, elongated green, with leaf length 45 to $75 \mathrm{~cm}$ and width 5 to $7.5 \mathrm{~cm}$. The flowers bloom at night. Crown of white flowers smell nice and bloom at night. Type of fruit is buni fruit, shaped like a ball with a shiny dark green color. This plant grows in the tropics and tolerant with drought so it has a considerable amount in the area of blue waterfall Kapas Biru. In the blue cotton waterfall area of the plant is used as an ornamental plant and a hedgerow plant with the aim of being a barrier on the parking area and pathways, and beautify the waterfall area.

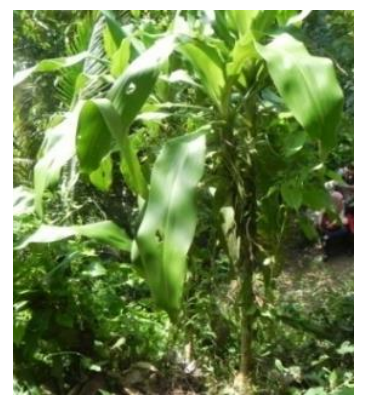

Figure. 4 Green Andong plants

(Personal Document)
The number of species of shrubs most fifth plant is Lantana camara L with the common name of the plant tembelekan, has the number of plants as many as 44 plants. Distribution of this species is found in the area of the path divided into 2 point coordinates on Gps, the first point is on the coordinates S $08^{0} 13.551 \mathrm{E} 112^{0} 56.275$, and the second point is on the coordinates $\mathrm{S}$ $08^{0} 13.322$ E112 56.470 . The crops can be recognized in nature, through the smell of leaves and flowers are strongly aromatic, while in terms of morphology of these plants can be identified through the woody stems and rectangular shaped and there is a spike stick on the surface. Leaf shape, ovoid with a dull root and pointed tip and jagged edges. The upper side of the coarse hairy strands and on the underside of the furry bottom. The color of the crown of flowers is a mix of red and orange, or purple and pink. The type of fruit that is stone fruit, arranged each other round-shaped, and blue-purple [21]. This species of octopus has an allelopathic substance, in which the function of this substance inhibits germination and growth of saplings, or to kill other plant species without affecting the growth of the invasive plant seedling seedlings themselves [28]. Subelopathy is one of the proponents of the spread of invasive foreign plants extends in the area of blue waterfall Kapas. In addition, it has no natural enemies due to its hairy leaves, its stems are thorny, and its aroma is not favored by animals [15].

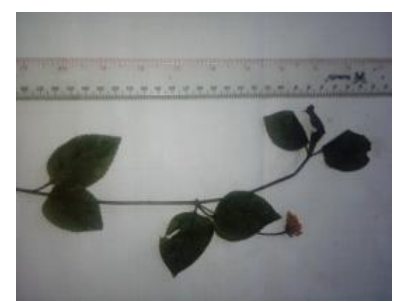

Figure 5. Images of Tembelekan Plants (Personal Document)

The least number of shruby habitation seed plants is Polyscias scutellaria (Burm. F.) Fosberg with the general name of mangkokan. This 
mangkokan plant has a uniqueness that is in the form of the leaves are like a liver to the oval with a curved edge upwards like a bowl. This plant can grow from lowland to a height of $700 \mathrm{~m}$ asl [12]. Distribution of this species is only found around the area under the waterfall, and at 1 GPS coordinates at, coordinates S $08^{0} 13.296$ $\mathrm{E} 112^{0} 56.456$. The number of plants found in this study only 1 plant. Habitat of this plant when found to be on the edge of the river and very close to the water. It is this that causes the number of these species to be small, new individuals either vegetatively grown or fallen fruits will be swept away when water discharges rise, other than that it is a plant that is difficult to flower and bear fruit.

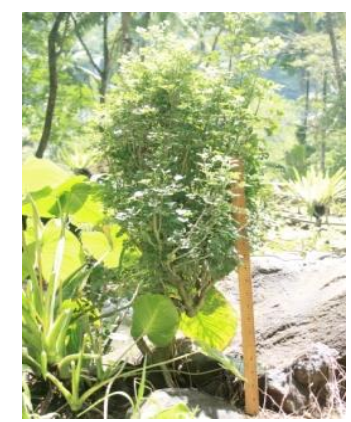

Figure 6. Mangkokan plants (Personal Document)

The number of shrubs of at least the second is Citrus $X$ aurantiifolia with the common name of Lime. Number of plants found in the Blue Cotton waterfall area as much as 2 plants. The distribution of this species is found only in the parking area, at 1 point coordinates at $\mathrm{Gps}$ ie at point $\mathrm{S}$ $08^{0} 13.348$ E112 56.192 . Plants belonging to the family Rutaceae, the community is utilized from the fruit and leaves, as a natural spice penye -ap on cooking. The number of plants is little found in the waterfall because this plant is only planted as a garden yard, which planted managers in the parking area, to be used by the surrounding community. Terms of growing lemon plants that is, can grow at an altitude of 200 to $1300 \mathrm{~m}$, with wet months 5 to 12 months and dry months 0 to 6 months. The air temperature is 200 to $300 \mathrm{C}, \mathrm{Ph} 5$ to 9 , and requires moderate irradiation. From abiotic data, the area of Blue Cotton waterfall, is a suitable area for this plant to grow

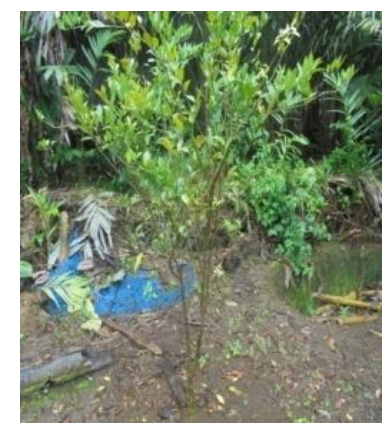

Figure 7. Lemon Plants (Personal Document)

The number of shrub species at least three is Jasmimum sambach with common name of jasmine plant. In this study the plant was found as many as 3 plants. The distribution of this species is found only in the parking area, at 1 point coordinates at Gps ie at point $\mathrm{S} 08^{0} 13.348 \mathrm{E} 112^{0} 56.192$. This plant is classified into shrub plants, jasmine plants are also classified into ornamental plants. This plant is easily recognizable from the flowers are white and smell very fragrant. The number of plants in the area of this area is small, because these plants are plants from outside that are planted in the area of waterfall area with the aim as an ornamental plant.

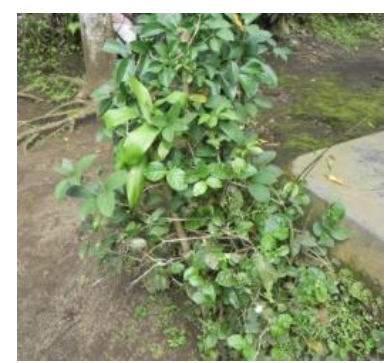

Figure 8. Jasmine Plants (Personal Document)

The number of shrubbed habitation plants is at least the fourth ie Datura metel $\mathrm{L}$ with the common name Amethyst. This amethyst has a uniqueness that is in shape like a large white bell and its fruit is round and small spiny around it. Distribution of 
this species is only found around the area under the waterfall, and at 1 GPS coordinates ie, coordinates $\mathrm{S}^{0} 8^{0} 13.278$ E112 56.440 . The number of plants found in this study as many as 5 plants. Habitat of this plant when found to be on the edge of the river and very close to the water. It is this that causes the number of these species a little, falling fruits, will carry the flow of water downstream of the river.

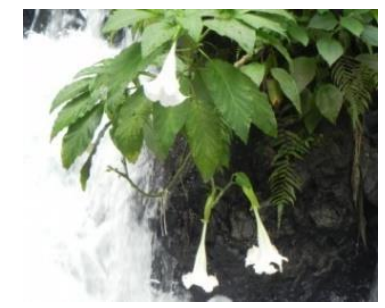

Figure 9. Amethyst (Personal Document)

\section{CONCLUSION}

Based on the results of identification that has been done in the area of Blue Cotton Waterfall, the result of Berabit Berbiji Berhabitus Perdu is 562 individuals and consists of 19 species. Dracaena fragrans, Cordyline Fruticosa LA Cheval, Citrus $\mathrm{X}$ aurantiifolia, Pluchea indica, Acalipha siamensis Oliv.ex Gage, Codiaeum variegatum, Claoxylon longifolia (Blume) Endl.ex Hassk, Ixora coccinea L, Lasianthus cf purpureus Blume, Coffea canephora, Mussaenda frondosa, Jasminum sambach, Salacca zalacca, Duranta erecta L, Lantana camara L, Clidemia hirta (L.) D. Don, Solanum torvum Sw, Datura metel L and Polyscias scutellaria (Burm. F.) Fosberg.

\section{REFERENCE}

[1]Branwell, D (2001). Wild flower of the canary island (2nd ed). Madrid:Rueda.ISBN

[2]Cullen,James., $\mathrm{Hu}$ er cao ke., Pan Jintang, Gu Bruce Bartholomew, Richard J. Gornal, Ulla-Maj Hultgård, Hideaki Ohba, Douglas E.
Soltis.2001. Saxifragales. Flora of China 8: 269-452

[3]Davis AP, Govaerts R.Bridson DM, Ruhsam M,Moat ,J Brummit NA (2009)."A global assessment of distribution, diversity, endemism, and taxonomic effort in the Rubiaceae" Annals of the Missouri Botanical Garden 96(1):68-78

[4]Dinas Kebudayaan Dan Pariwisata Kabupaten Lumajang.2015.

Program Dan Kegiatan Tahun Anggaran 2015.Lumajang.Pemerintah Kabupaten Lumajang

[5]Eko, W.2016.Pemkab Tandatangani Mou dengan Perhutani, 3 Danau di Utara Jadi Prioritas Utama, [online], (http://wartalumajang.com/pemkabtandatangani-mou-dengan-perhutani3-danau-di-utara-jadi-prioritaspertama diakses 19 February 2017).

[6]Firmansyah, R.2009.Mudah dan aktif belajar biologi 3: untuk kelas XII Sekolah Menengah Atas / Madrasah Aliyah Program Ilmu Pengetahuan Alam. Pusat Perbukuan, Departemen Pendidikan Nasional, Jakarta, p.218

[7]Hasyim.2009. Tanaman Flora Indonesia .Jakarta: Swadaya

[8]Indrawan, Mochamad., Richard B. Primack, Jatna Supriatna. (2007). Biologi Konservasi.Jakarta: Yayasan Obor Indonesia

[9] Indriyanto. 2008. Ekologi Hutan. Jakarta.Bumi Aksara.

[10]Qomah, Isti.2015. Identifikasi Tumbuhan Berbiji (Spermatophyta) Di Lingkungan Kampus Universitas Jember Dan Pemanfaatannya Sebagai Booklet Tidak Publikasikan. 
Skripsi. Jember: Program Studi Pendidikan Biologi FKIP Universitas Jember.

[11]Kementerian Pendidikan dan Kebudayaan, 2015. Ilmu Pengetahuan Alam. Jakarta: Kementerian Pendidikan dan Kebudayaan Indonesia

[12]Lestari, Agnesia., Ismaini, Lily. 2015. Potensi Alelopati Clidemia Hirta sebagai Bioherbisida. Volume 1, Nomor 6 ISSN: 2407-8050

[13]Melisa, Fenny.2012. Ini Dia Penyebab Punahnya Tumbuhan Indonesia. http://www.republika.co.id/berita/tre ndtek/sains/12/10/03/mbbe6y-inidia-penyebab-punahnya-tumbuhanindonesia [12 February 2017]

[14]Mursito, Bambang. 2007. Ramuan Tradisional untuk Pengobatan Jantung. Jakarta: Penebar Swadaya.

[15]Nasution, A. $\quad$ N. 2014. Keanekaragaman dan Pola Penyebaran Spesies Tumbuhan Asing Invasif di Semenanjung Praparat Agung, Taman Nasional Bali Barat. Skripsi. Fakultas Kehutanan. Institut Pertanian Bogor. Bogor.

[16]Nugroho, Susatyo., Anis, Tria., Ulfah, Maria.2015. Analisis Keanekaragaman Jenis Tumbuhan Berbuah Di Hutan Lindung Surokonto, Kendal, Jawa Tengah Dan Potensinya Sebagai Kawasan Konservasi Burung. Volume 1, Nomor 3: ISSN: 2407-8050

[17]RPJMD Lumajang. 2015. Gambaran Umum Kondisi Daerah Kabupaten Lumajang., [online], (https://lumajangkab.go.id/rpjmd201 5/3.\%20Bab2\%20(Kondisi\%20Daer
ah\%20Lumajang).pdf 'diakses tanggal 11 February 2017).

[18]Santoso.1990. Salak Pondoh.Kanius: Yogyakarta

[19]Sastroprodjo, S.1980.Fruits.IBPGR Scretariat HomeSofro. Yogyakarta: Andi Offset

[20]Setiowati, T.,dan Furqonita ,D.2007.Biologi Interaktif. Jakarta: Azka Press

[21]Steenis CGJ.2010.Flora Pegunungan Jawa.Penerjamah:Jenny A. Kartawinata. Bogor:LIPI Press.

[22]Suryani, Tri Vivi.2008. Galeri Puring.Jakarta.Penebar Swadaya

[23]Syukur, C., dan Hernani.2002. Budidaya Tanaman Obat Komersial. Penebar Swadaya. Jakarta

[24]Tjitrosoepomo, G. 2004. Taksonomi Tumbuhan (Spermatophyta). Cetakan ke-8.Yogyakarta: UGM Press. hlm. 458

[25]Tonny, Laksmita, Prabaningrum., Witona, Adiyoga., Herman. 2015. Budi Daya Cabai Merah, Tomat, dan Mentimun Berdasarkan Konsepsi Pengendalian Hama terpadu. Wageningen UR, the Netherland

[26]Utomo. Salak Pondoh. Kanisius. Yogyakarta. 54h

[27]Widiastuti, L., Tohari, dan E. Sulistyaningsih. 2004. Pengaruh Intensitas Cahaya dan Kadar Daminosida terhadap Iklim Mikro dan Pertumbuhan Tanaman Krisan dalam Pot. Jurnal Ilmu Pertanian. 11 (2): $35-42$

[28]Yuliani.S. 2013. Analisis Komponen Minyak Atsiri dari Daun 
Tembelekan (Lantana camara L)

secara Kromatografi Gas-

Spektrometri Massa

(GCMS).[Skripsi].

Medan.Universitas Sumatera Utara,

Program Sarjana.

[29]Yuniawati. 2011. Estimasi Potensi Biomassa dan Massa Karbon Hutan Tanaman Acacia crassicarpa di Lahan Gambut (Studi Kasus di Areal HTI Kayu Serat di Pelalawan, Provinsi Riau). Institut Pertanian Bogor. Bogor. 